\title{
Radiation-induced esophagitis in lung cancer
}

\author{
This article was published in the following Dove Press journal: \\ Lung Cancer:Targets and Therapy \\ 13 October 2016 \\ Number of times this article has been viewed
}

\author{
Sarah Baker \\ Alysa Fairchild \\ Department of Radiation Oncology, \\ Cross Cancer Institute, University of \\ Alberta, Edmonton, AB, Canada
}

\begin{abstract}
Radiation-induced esophagitis is the most common local acute toxicity of radiotherapy (RT) delivered for the curative or palliative intent treatment of lung cancer. Although concurrent chemotherapy and higher RT dose are associated with increased esophagitis risk, advancements in RT techniques as well as adherence to esophageal dosimetric constraints may reduce the incidence and severity. Mild acute esophagitis symptoms are generally self-limited, and supportive management options include analgesics, acid suppression, diet modification, treatment for candidiasis, and maintenance of adequate nutrition. Esophageal stricture is the most common late sequela from esophageal irradiation and can be addressed with endoscopic dilatation. Approaches to prevent or mitigate these toxicities are also discussed.
\end{abstract}

Keywords: non-small cell lung cancer, acute, late, toxicity, stricture

\section{Introduction}

Radiation-induced esophagitis is a frequent and dose-limiting toxicity of thoracic radiotherapy (RT), especially when delivered concurrently with cytotoxic chemotherapy. The specific incidence is sensitive to the timing and methods used to measure it. ${ }^{1}$ For example, acute dysphagia resulting from irradiation of the esophagus was reported in one study on $13 \%$ of patients' quality of life questionnaires, $18 \%$ of weekly physician ratings, and in $28 \%$ of patients' verbal descriptions. ${ }^{2}$ In a meta-analysis of 13 palliative thoracic RT studies, physician-assessed dysphagia was more common after higher versus lower RT schedules $(20.5 \%$ vs $14.9 \% ; P=0.01)$; however, pooling of patients' self-report data could not be performed due to heterogeneity. ${ }^{3}$

RT esophagitis can be classified as acute or late. The time frame of acute side effects is generally taken to mean $\leq 3$ months after completion of treatment, although RT esophagitis most commonly onsets 2-3 weeks after the initiation of RT, lasting up to 4 weeks after RT completion. ${ }^{3,4}$ Symptoms tend to be cumulative, may peak after RT is finished, are generally self-limited, and can be addressed by conservative supportive care measures. ${ }^{1}$ As it is a predictable side effect of RT, esophagitis should probably not be described as a "complication" unless it is significant enough to interfere with the planned treatment.

By definition, "late" refers to $>3$ months after the completion of RT; median time of onset of late esophageal injury is 6 months, ${ }^{5}$ with some instances diagnosed at 1 year or later. ${ }^{1}$ Late side effects more often require invasive management such as surgical intervention, and even then may not be reversible. ${ }^{1}$ Although RT dose schedules are generally chosen to limit the risk of long-term side effects to $\leq 5 \%$, prevalence depends on the proportion of patients alive and at risk after treatment, and whether they are
Correspondence: Alysa Fairchild Department of Radiation Oncology, Alberta, II 560 University Avenue, Edmonton, AB, T6G IZ2, Canada

$\mathrm{Tel}+\mathrm{I} 7804328783$

Fax +I 7804328380

Email alysa.fairchild@

albertahealthservices.ca 
pretreatment dysphagia. ${ }^{19}$ De Ruysscher et al reported that worse neutropenia during CRT correlated with higher maximal dysphagia. ${ }^{21}$ Higher tumor and nodal stage ${ }^{19}$ and the presence of N2 disease are associated with higher rates of esophagitis, likely as surrogates for the volume of esophagus irradiated. Esophageal erosion secondary to tumor is also associated with higher rates, ${ }^{16}$ and tumors infiltrating the esophagus or proximal bronchial tree especially may put patients at risk of late fistula or perforation. Germline polymorphisms may render some patients more susceptible to injury than others. ${ }^{5}$

\section{Treatment factors}

Factors that contribute to RT toxicity include volume of tissue irradiated, total dose, dose per day (fraction size),

Table 3 Incidence rates of acute esophagitis with different treatment RT techniques for non-small cell lung cancer

\begin{tabular}{|c|c|c|c|c|}
\hline Treatment & Regimen $^{a}$ & Technique / N & Acute esophagitis & Reference \\
\hline \multirow{9}{*}{$\begin{array}{l}\text { Curative-intent } \\
\text { conventional RT } \\
\text { with concurrent } \\
\text { cytotoxic } \\
\text { chemotherapy }\end{array}$} & $\begin{array}{l}\text { - } 60 \text { Gy or } 74 \text { Gy } \\
\text { - Carboplatin and paclitaxel }\end{array}$ & $\begin{array}{l}\text { IMRT or 3DCRT } \\
\mathrm{N}=544\end{array}$ & $\begin{array}{l}\text { - } \geq \text { Grade } 3^{\mathrm{d}}: 21 \% \text { vs } 7 \% \\
\text { - } \geq \text { Grade } 4: 0\end{array}$ & 28 \\
\hline & $\begin{array}{l}\text { - Median dose 65Gy } \\
\text { - Platinum-based chemotherapy }\end{array}$ & $\begin{array}{l}\text { IMRT or 3DCRT } \\
\mathrm{N}=1,082^{\mathrm{b}}\end{array}$ & $\begin{array}{l}\text { - Grade 2: } 32.2 \% \\
\text { - Grade 3: } 17.1 \% \\
\text { - Grade } 4: 0.9 \% \\
\text { - Grade } 5: 0\end{array}$ & 27 \\
\hline & $\begin{array}{l}\text { - } 69.6 \mathrm{~Gy} / 58 \text { delivered as I.2 Gy BID } \\
\text { - Cisplatin and etoposide }\end{array}$ & \multirow{3}{*}{$2 \mathrm{D} / \mathrm{N}=528^{\mathrm{b}}$} & \multirow{3}{*}{$\begin{array}{l}\text { - } \geq \text { Grade } 2: 75 \% \text { of patients (no difference } \\
\text { between arms) } \\
\text { - } \geq \text { Grade 3: } 70 \% \text { in hyperfractionated arm } \\
\text { vs } 22 \% \text { in standard RT arms }(P<0.000 \text { I) } \\
\text { - } \geq \text { Grade } 4: 2 \%\end{array}$} & \multirow{3}{*}{10} \\
\hline & $\begin{array}{l}\text { - } 63 \text { Gy } \\
\text { - Cisplatin and vinblastine }\end{array}$ & & & \\
\hline & $\begin{array}{l}\text { - } 69.6 \mathrm{~Gy} \\
\text { - Cisplatin and vinblastine }\end{array}$ & & & \\
\hline & $\begin{array}{l}\text { - } 60 \mathrm{~Gy} \\
\text { - Sequential cisplatin and vinblastine } \\
\text { or etoposide }\end{array}$ & \multirow{3}{*}{$2 \mathrm{D} / \mathrm{N}=46 \mathrm{I}^{\mathrm{b}}$} & - Grade $\geq 3:$ I.3\% & \multirow{3}{*}{24} \\
\hline & $\begin{array}{l}\text { - } 60 \text { Gy } \\
\text { - Sequential and concurrent cisplatin } \\
\text { and vinblastine or etoposide }\end{array}$ & & - Grade $\geq 3: 6 \%$ & \\
\hline & $\begin{array}{l}\text { - } 69.6 \text { Gy/58 delivered as } 1.2 \text { Gy BID } \\
\text { - Concurrent cisplatin and vinblastine } \\
\text { or etoposide }\end{array}$ & & - Grade $\geq 3^{\mathrm{d}}: 34 \%$ & \\
\hline & $\begin{array}{l}\text { - Concurrent CRT } \\
\text { - Sequential CRT }\end{array}$ & $\begin{array}{l}\text { 2D in five trials } \\
\text { 3DCRT in one trial } \\
\mathrm{N}=1,205^{\mathrm{b}}\end{array}$ & $\begin{array}{l}\text { - Grades 3-4: } 4 \% \text { with sequential and I8\% } \\
\text { with concurrent CRT (RR 4.9; } 95 \% \\
\text { Cl } 3.1-7.8, P<0.0 \text { I) }\end{array}$ & 63 \\
\hline $\begin{array}{l}\text { CHART versus } \\
\text { curative-intent } \\
\text { conventional RT }\end{array}$ & $\begin{array}{l}\text { - } 54 \text { Gy/36 delivered as I.5 Gy TID } \\
\text { over I } 2 \text { consecutive days (CHART) } \\
\text { - } 60 \text { Gy (conventional) }\end{array}$ & $2 \mathrm{D} / \mathrm{N}=563$ & $\begin{array}{l}\text { - Acute severe dysphagia: 19\% (CHART) } \\
\text { vs 3\% (no P-value) }\end{array}$ & 26 \\
\hline \multirow[b]{2}{*}{ SBRT } & - $45 \mathrm{~Gy} / 5$ & $\mathrm{SBRT} / \mathrm{N}=108$ & $\begin{array}{l}\text { When median esophageal maximum } \\
\text { dose }>30 \text { Gy, grade }>2 \text { esophagitis seen } \\
\text { in } 50 \% \text { when target volume overlapped } \\
\text { the esophagus }\end{array}$ & 64 \\
\hline & - $54 \mathrm{~Gy} / 3^{\mathrm{c}}$ & $\mathrm{SBRT} / \mathrm{N}=44$ & $\begin{array}{l}\text { Gl adverse events: } \\
\text { - Grade I: } 7.3 \% \\
\text { - Grade } 2: 1.8 \% \\
\text { - Grade 3: } 1.8 \% \\
\text { - Grade } 4-5: 0 \%\end{array}$ & 65 \\
\hline \multirow{2}{*}{$\begin{array}{l}\text { Palliative-intent } \\
\text { conventional RT }\end{array}$} & $\begin{array}{l}25 \text { Gy/l0 followed by } 2 \text { week break, } \\
\text { followed by } 25-32.5 \text { Gy/l0-13 (split } \\
\text { course) }\end{array}$ & $\begin{array}{l}2 \mathrm{D} \text { or } 3 \mathrm{DCRT} \\
\mathrm{N}=140\end{array}$ & $\begin{array}{l}\text { Acute esophagitis: } \\
\text { - Mild } 34 \% \\
\text { - Moderate to severe } 10 \%\end{array}$ & 30 \\
\hline & - Various regimens ${ }^{\mathrm{e}}$ & $\begin{array}{l}\text { 2D or } 3 D C R T \\
N=3473^{b}\end{array}$ & $\begin{array}{l}\text { Physician-assessed dysphagia: } \\
\text { - Low-dose regimens: } 15 \% \\
\text { - High-dose regimens: } 21 \%\end{array}$ & 3 \\
\hline
\end{tabular}

Notes: aStandard fractionation of I.8-2 Gy per day unless otherwise specified. ${ }^{\mathrm{b}}$ Meta-analysis. ${ }^{\mathrm{C}} \mathrm{TI}$ or T2 tumors $>2 \mathrm{~cm}$ from proximal bronchial tree. ${ }^{\mathrm{d}} \mathrm{Significantly} \mathrm{higher} \mathrm{in}$ higher RT dose arm. étow-dose regimens delivered $<35 \mathrm{~Gy} / \mathrm{I} 0$ and high-dose regimens delivered $>35 \mathrm{~Gy} / \mathrm{I} 0$.

Abbreviations: 2D, two dimensional; 3DCRT, three-dimensional conformal radiation therapy; BID, twice per day; CHART, continuous hyperfractionated accelerated radiation therapy; IMRT, intensity-modulated radiation therapy; RT, radiotherapy; SBRT, stereotactic body radiotherapy; TID, three times per day. 
overall treatment time, concurrent systemic therapy, and RT technique (Table 3). 1,8,22

A meta-analysis of 19 randomized trials of radical CRT versus RT alone, including concurrent and sequential systemic therapy, reported that the addition of chemotherapy increases acute esophagitis by approximately five times. ${ }^{23}$ In a study by Byhardt et al in patients with locally advanced NSCLC, the incidence of severe acute esophagitis with standard RT alone (60-69 Gy/30) was 1.3\%; concurrent chemotherapy increased this to $14 \%-49 \%{ }^{24}$ In esophageal cancer, as an example, when systemic therapy is given in conjunction with RT, symptomatic toxicity occurs on average 1 week earlier, higher proportions of patients cannot complete planned treatment, and there is a higher risk of treatment-related death. ${ }^{17,25}$

Radical RT alone results in significantly lower rates of grade 3 or higher esophagitis $(1 \%-2 \%) .{ }^{24}$ Hyperfractionated and hyperfractionated accelerated RT techniques have high rates of esophagitis ${ }^{10,26}$ even without the addition of chemotherapy and have not conclusively improved survival outcomes, so are not in common use.

RT from different eras is not directly comparable in terms of likelihood of toxicity: older techniques using twodimensional (2D) planning and lower energy machines such as Cobalt-60 are more likely to cause side effects than modern technologies. ${ }^{1}$ 2D RT techniques with concurrent chemotherapy result in grade 2 esophagitis in $75 \%$, grade 3 in $22 \%$, and grade 4 in $2 \%$ of patients. ${ }^{10}$

The emergence of advanced three-dimensional conformal RT and especially intensity-modulated RT results in more precise dose delivery to the target and therefore more sparing of normal structures such as the esophagus. In comparison with the aforementioned 2D incidences, using 3D conformal RT or intensity-modulated RT to deliver CRT results in grade 2 esophagitis in $32 \%$, grade 3 in $17 \%$, and grade 4 in $0.9 \%{ }^{27}$ Approximately $10 \%-20 \%$ of patients undergoing modern CRT will experience grade 3 esophagitis, which by definition indicates severely altered swallowing requiring hospitalization and/or TPN or tube feeding (Table 1). ${ }^{27,28}$ The potential gains in toxicity rates of these techniques must be weighed against the increased cost, time, and resources required for planning and treatment, ${ }^{1}$ and a steep institutional learning curve in achieving lower rates of toxicity seems to exist. ${ }^{7}$

Palliative regimens are the most frequently prescribed RT schedules for patients with NSCLC, as 75\%-85\% of patients present with incurable disease. ${ }^{29}$ While a lower total dose is usually delivered, often $30 \mathrm{~Gy}$ in 10 daily fractions, the relatively high daily dose still carries a risk of esophagitis: mild in $34 \%$ and moderate to severe esophagitis in $10 \%$ (Table 3 ). ${ }^{30}$

\section{Prevention: dose constraints for acute esophagitis}

Parameters from the Quantitative Analyses of Normal Tissue Effects in the Clinic report provide estimates of acute esophagitis risk in relation to mean organ dose (eg, mean dose to the entire esophagus $<34$ Gy results in 5\%-20\% incidence of grade $>3$ esophagitis). ${ }^{31}$ Other parameters reported as predictive include maximal esophageal point dose (69 Gy for RT alone and $58 \mathrm{~Gy}$ with concurrent chemotherapy), and percentage of esophageal surface area receiving $>50 \mathrm{~Gy}{ }^{16,32,33}$ An individual patient data meta-analysis including 1,082 patients undergoing curative-intent CRT for locally advanced NSCLC found that esophageal volume receiving $\geq 60$ Gy (V60) was the best predictor, with a $\mathrm{V} 60<0.07 \%$ associated with $<5 \%$ risk of grade 3 or higher esophagitis, but V60 $\geq 17 \%$ conferring a $59 \%$ risk of grade $\geq 2$ and $22 \%$ of grade $\geq 3$ esophagitis. ${ }^{27}$ A previous analysis of 12 studies described no single best parameter but noted that higher esophageal volumes receiving $>40-50$ Gy correlated with higher rates of acute esophagitis. ${ }^{34}$ Other authors have reported maximum point dose exceeding $55 \mathrm{~Gy}$ and esophageal surface area receiving a dose exceeding 58 Gy as predictive. ${ }^{32,33}$ Figure 1 demonstrates the RT plan and esophageal dosimetric indices of a patient who developed grade 3 esophagitis requiring hospital admission and a treatment break.

\section{Prevention: dose constraints for late esophageal toxicity}

Emami et al estimated the dose at which 5\% of patients develop stricture or perforation at 5 years to be 60 Gy when one-third of the esophagus length was irradiated, $58 \mathrm{~Gy}$ when two-thirds was irradiated, and 55 Gy after irradiation of the entire esophagus. ${ }^{35}$ With one-third of the esophagus irradiated to $72 \mathrm{~Gy}, 50 \%$ of patients developed late complications at 5 years. ${ }^{35}$ However, it must be acknowledged that these results are inferred largely on the basis of historic techniques.

\section{Prevention: systemic agents}

Amifostine, an organic thiophosphate, has been studied as a potential radioprotective agent. The active metabolite WR-1065 acts as a scavenger of the free-oxygen radicals produced by ionizing radiation, ${ }^{36}$ and early reports suggested the potential to reduce RT esophagitis without compromising tumor control. ${ }^{36-39}$ A subsequent phase III study in locally advanced NSCLC patients undergoing CRT, however, found no significant reduction in grade 3 or higher esophagitis. ${ }^{40}$ It did improve swallowing dysfunction and pain based on 
A

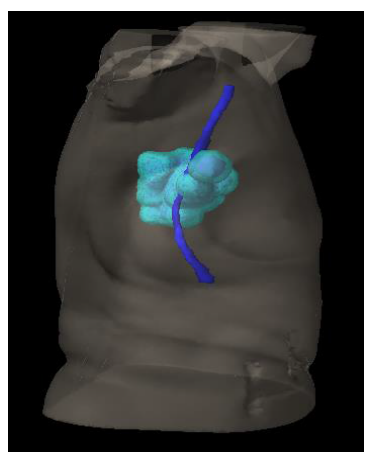

C

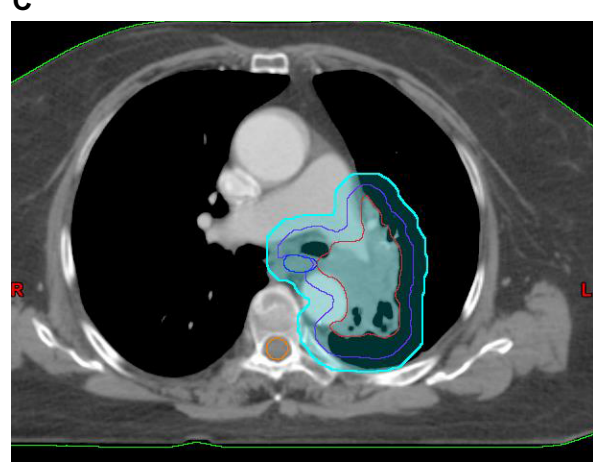

$\mathbf{E}$

\section{B}

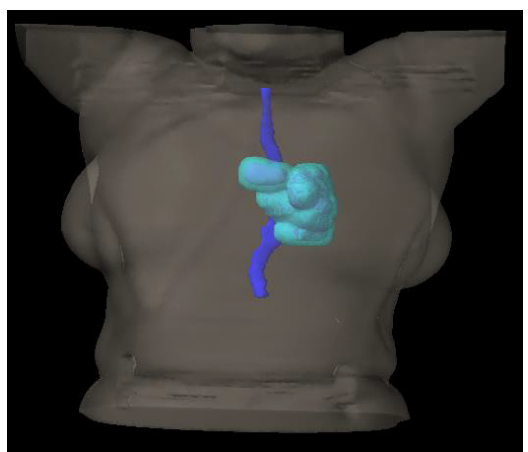

D

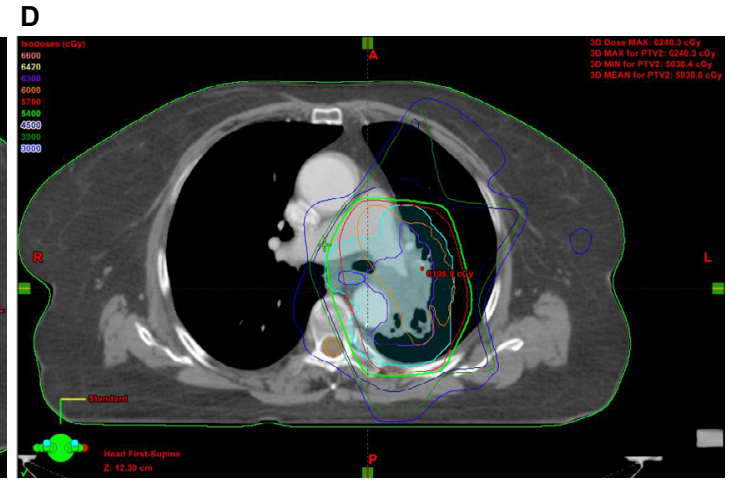

$\mathbf{F}$

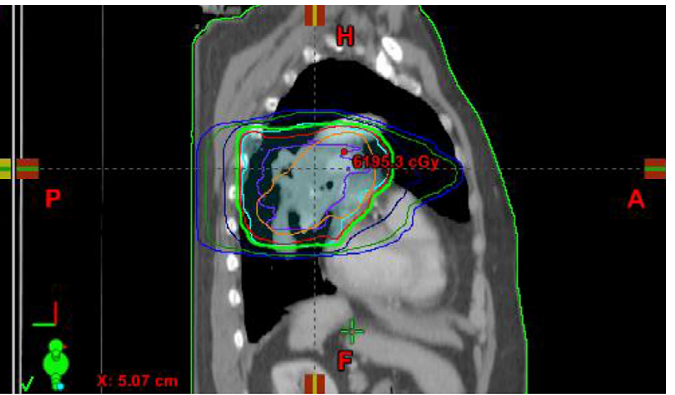

Figure I A 73-year-old woman with unresectable T4N2 squamous cell carcinoma (left hilum/AP window) treated with concurrent radiotherapy (60 Gy/30) with cisplatin and etoposide chemotherapy. (A) Sagittal view of radiotherapy target volume (cyan) and esophagus (blue). (B) Coronal view of radiotherapy target volume (cyan) and esophagus (blue). (C) Axial view of target volumes (gross tumor = red, clinical target volume = purple, planning target volume = cyan), spinal cord (orange), and esophagus (blue). (D) Axial image of isodose lines demonstrating dose received by tumor and esophagus. (E) Coronal image of isodose lines demonstrating dose received by tumor and esophagus. (F) Sagittal image of isodose lines demonstrating dose received by tumor and esophagus. Her first cycle of chemotherapy was concurrent with her second week of RT, and the second cycle was concurrent with her sixth week. After the 17th fraction, she described minor odynopaghia, which was treated with oral viscous lidocaine. She used liquid nutritional supplements and maintained her weight into her fifth week of therapy. She required admission to hospital with grade 3 esophagitis after the 27 th fraction (6 days after day I of cycle 2 of chemotherapy) with severe burning epigastric/substernal pain, dysphagia, odynophagia, and occasional nausea. She was dehydrated, in acute renal failure, and had superimposed febrile neutropenia. She required a I-day break from RT but improved quickly with aggressive supportive therapy. She completed the remainder of her planned therapy and was discharged from hospital 6 days after completion of chemoradiotherapy. Review of the treatment plan indicates mean esophageal dose $24.2 \mathrm{~Gy}$, maximum point dose to esophagus $59.4 \mathrm{~Gy}$, and $31.8 \%$ of esophagus receiving $50 \mathrm{~Gy}$ or higher.

Abbreviations: A, anterior; AP, anteroposterior; L, left; P, posterior; R, right; RT, radiotherapy.

patients' self-report but was associated with higher rates of nausea, vomiting, cardiotoxicity, and febrile neutropenia. ${ }^{41}$ Currently, the American Society of Clinical Oncology recommends against the use of amifostine. ${ }^{42}$

Another potential radioprotective agent, glutamine, has been associated with lower rates of mucositis, weight loss, and TPN use based on a retrospective cohort study in patients with head and neck and thoracic malignancies. ${ }^{43}$ A small prospective trial included NSCLC patients treated prophylactically with glutamine powder and reported no esophagitis in $49 \%$ of those undergoing radical CRT and $73 \%$ receiving sequential CRT. ${ }^{44}$ A phase III trial is currently underway. ${ }^{45}$

Nonsteroidal compounds have been studied to prevent RT esophagitis but have not yet been proved effective. ${ }^{46,47}$ Nonrandomized trials have suggested the potential efficacy of granulocyte macrophage colony stimulating factor. ${ }^{48}$ The 
use of honey to prevent mucositis in head and neck patients has been demonstrated in several small randomized trials; ${ }^{49,50}$ however, in a phase II trial reported in abstract form, there was no added benefit of Manuka honey compared to standard care for reducing odynophagia in patients with lung cancer undergoing CRT. ${ }^{51}$

In the absence of systemic agents with a proven ability to prevent RT esophagitis, pretreatment supportive care consultation to optimize baseline status and quality of life, such as clinical nutrition referral, should be undertaken. ${ }^{1}$

\section{Diagnosis}

Acute radiation esophagitis can be generally diagnosed clinically and seldom is specific workup needed. Endoscopy is helpful not only in diagnosing and treating late esophageal strictures but also in differentiating radiation injury from infectious esophagitis (Table 4) ${ }^{52}$ Histologic findings typical of late RT esophagitis include chronic-appearing inflammation, fibrosis, and atypia in biopsies taken from the radiated field, ${ }^{53}$ with tissue sampling essential to rule out recurrent malignancy. ${ }^{5}$

\section{Management}

Optimal management (Table 5) of esophagitis is important to not only reduce morbidity and maintain patient quality of life

Table 4 Recommended workup for a patient previously irradiated for lung cancer and presenting with late-onset dysphagia

\begin{tabular}{|c|c|}
\hline Investigation & Findings \\
\hline $\begin{array}{l}\text { History and } \\
\text { physical } \\
\text { examination }\end{array}$ & $\begin{array}{l}\text { - Symptoms of recurrent disease (weight loss, } \\
\text { worsening respiratory status, hoarseness) } \\
\text { - Evaluate oral cavity for thrush } \\
\text { - Cervical or supraclavicular lymphadenopathy may } \\
\text { be suggestive of disease recurrence } \\
\text { - Respiratory examination can rule out aspiration } \\
\text { pneumonia }\end{array}$ \\
\hline $\begin{array}{l}\text { Barium } \\
\text { swallow }\end{array}$ & $\begin{array}{l}\text { - Esophageal stricture } \\
\text { - Impaired peristalsis is demonstrated by peristaltic } \\
\text { waves above and below the irradiated segment of } \\
\text { esophagus }\end{array}$ \\
\hline $\begin{array}{l}\text { CT chest/ } \\
\text { abdomen }\end{array}$ & $\begin{array}{l}\text { - Mediastinal lymphadenopathy causing extrinsic } \\
\text { esophageal compression } \\
\text { - Characterization of stricture(s) (location, number, } \\
\text { severity) } \\
\text { - Fistula }{ }^{\mathrm{a}}\end{array}$ \\
\hline $\begin{array}{l}\text { Upper } \\
\text { endoscopy }\end{array}$ & $\begin{array}{l}\text { - Stricture } \\
\text { - Ulceration } \\
\text { - Fistula } \\
\text { - Biopsy }\end{array}$ \\
\hline
\end{tabular}

Note: ${ }^{a}$ Bronchoscopy may be required if there is a concern regarding bronchoesophageal fistula.

Abbreviation: CT, computed tomography. but also prevent further nutritional deterioration. Although short treatment breaks can be considered for severe symptoms,${ }^{14}$ interruptions should be avoided if at all possible as they can decrease overall and disease-free survival. ${ }^{54}$

\section{Diet and nutritional support}

Certain foods including tobacco, alcohol, coffee, spicy foods, and very hot or very cold items may irritate the esophageal mucosa. ${ }^{55} \mathrm{~A}$ soft or pureed bland diet is preferred. A dietician assessment can provide estimates of daily nutritional requirements and advice for optimizing protein and calorie intake, such as use of liquid meal replacements. Patients with dysphagia to fluids will require intravenous fluid hydration. In patients with weight loss, tube feeding or TPN may be required. ${ }^{56}$ Although placement of a nasogastric tube may irritate esophageal mucosa, enteral feeding is generally preferred over parental nutrition due to lower rates of infection and faster return to normal intake. ${ }^{57}$ Interventional radiology placement of a gastrostomy tube can be alternatively considered.

Table 5 Management strategies for acute radiation esophagitis

\begin{tabular}{|c|c|c|}
\hline $\begin{array}{l}\text { Supportive } \\
\text { measure }\end{array}$ & Recommendation & Reference \\
\hline $\begin{array}{l}\text { Dietary } \\
\text { modification }\end{array}$ & $\begin{array}{l}\text { - Consider dietician referral } \\
\text { - Avoid potentially irritant foods } \\
\text { (tobacco, alcohol, coffee, and spicy } \\
\text { foods) } \\
\text { - Soft, bland diet } \\
\text { - Small, frequent meals }\end{array}$ & 56 \\
\hline $\begin{array}{l}\text { Nutritional } \\
\text { support }\end{array}$ & $\begin{array}{l}\text { - Liquid meal replacements/ } \\
\text { supplements } \\
\text { - Intravenous hydration } \\
\text { - Electrolyte correction } \\
\text { - For prolonged symptoms, enteral } \\
\text { feeding or total parenteral nutrition } \\
\text { may be required, although former is } \\
\text { preferred } \\
\text { - Antiemetics may be beneficial }\end{array}$ & $1,55,57$ \\
\hline Analgesics & $\begin{array}{l}\text { - Topical analgesics (viscous lidocaine, } \\
\text { liquid morphine sulfate, "Pink Lady", } \\
\text { benzydamine mouthwash) } \\
\text { - Opioid analgesics often required } \\
\text { - Combination solutions containing a } \\
\text { topical analgesic, antacid, and } \\
\text { nystatin may be particularly effective }\end{array}$ & $1,55,56$ \\
\hline $\begin{array}{l}\text { Acid } \\
\text { suppression }\end{array}$ & $\begin{array}{l}\text { - Proton-pump inhibitors } \\
\text { - }{ }^{\mathrm{b}} \\
\text { - Antacids }\end{array}$ & 9,55 \\
\hline $\begin{array}{l}\text { Antifungal } \\
\text { treatment }\end{array}$ & $\begin{array}{l}\text { - Nystatin solution }{ }^{\mathrm{a}} \\
\text { - Oral antifungals may be required for } \\
\text { refractory cases }\end{array}$ & 53,56 \\
\hline
\end{tabular}

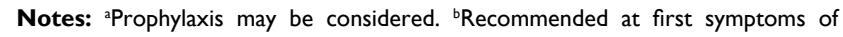
esophagitis. 


\section{Symptomatic management}

Mild to moderate odynophagia responds to topical analgesics such as oral viscous lidocaine. ${ }^{55}$ Treatment with nonsteroidal anti-inflammatory agents has been proposed ${ }^{56}$ since murine models demonstrate elevated prostaglandins following RT; 9 however, opioid analgesics such as morphine are often necessary. Significant dysphagia typically requires a liquid formulation or intravenous, subcutaneous, or transdermal route of analgesic administration.

Patients with esophagitis have reduced lower esophageal sphincter pressure and are prone to reflux and should be prescribed a proton-pump inhibitor (PPI) or $\mathrm{H} 2$ receptor blocker. ${ }^{9}$ Proton-pump inhibitors, but not $\mathrm{H} 2$ receptor blockers, may reduce the healing time for erosive esophagitis. ${ }^{58}$ Antacids can provide symptomatic relief and help prevent candida infection based on their alkalotic properties. ${ }^{56}$

Prophylactic antifungal agents are recommended due to a high incidence of thrush and candidal esophagitis, particularly in patients receiving chemotherapy or steroids. Mixtures containing nystatin and equal parts of viscous xylocaine $2 \%$, aluminum hydroxide-magnesium carbonate, and diphenhydramine can concurrently manage odynophagia and treat thrush. ${ }^{53}$ Nitrates or calcium-channel blockers may be effective for esophageal spasm, ${ }^{14}$ and prokinetic agents such as metoclopramide help address dysfunctional peristalsis. ${ }^{14,55}$

An early trial randomizing esophageal cancer patients to sucralfate or a control antacid containing sodium alginate reported significant symptom relief in $80 \%$ of patients treated with sucralfate compared to $10 \%$ of patients receiving the control and faster ulcer healing with sucralfate. ${ }^{59}$ However, a subsequent study found minor relief of symptoms in only $40 \%$ of patients and showed with $\mathrm{TC}^{99 \mathrm{~m}}$-labeled sucralfate that the suspension adhered to the esophageal mucosa for a short period of time. ${ }^{60} \mathrm{McGinnis}$ et al reported that sucralfate did not improve esophagitis in patients undergoing thoracic RT compared to placebo and actually found high rates of gastrointestinal toxicity ( $58 \%$ of sucralfate patients versus $14 \%$ of placebo, $P<0.0001) .{ }^{61}$

\section{Dilatation for esophageal stenosis}

Dysphagia, especially when resulting in weight loss, is an indication for dilation of late esophageal stricture. ${ }^{5}$ Multiple dilatation procedures may be required for achievement of a minimum luminal diameter of $13 \mathrm{~mm}$, which is needed for sustained symptomatic improvement. ${ }^{62}$ Major complications with dilatation include bleeding and aspiration, with a perforation risk of $<0.4 \% .{ }^{5}$ Gastrostomy tube feeding is recommended in the setting of strictures resistant to endo- scopic dilatation to maintain adequate nutritional status, as is continued acid suppression with proton-pump inhibitor therapy. ${ }^{5}$

\section{Conclusion}

Despite improvements in RT delivery techniques, treatmentinduced esophagitis continues to be a common and at times severe side effect for patients undergoing treatment for lung cancer. With aggressive symptomatic intervention and nutritional support, few patients require treatment breaks. Ongoing research in radioprotective agents and continued refinements of RT, such as adaptive image-guided therapy, may continued reduce the detrimental impact of acute and late esophageal toxicity in the future.

\section{Disclosure}

The authors report no conflicts of interest in this work.

\section{References}

1. Fairchild A. Chapter 5: Side effects of palliative radiation therapy. In: Lutz S, Chow E, Hoskin P, editors. Radiation Oncology in Palliative Cancer Care. West Sussex, UK: Wiley-Blackwell; 2013:43-60.

2. Kassam Z, Wong R, Ringash J, et al. A phase I/II study to evaluate the toxicity and efficacy of accelerated fractionation radiotherapy for the palliation of dysphagia from carcinoma of the esophagus. Clin Oncol. 2008;20(1):53-60.

3. Fairchild A, Harris K, Barnes E, et al. Palliative thoracic radiotherapy for lung cancer: a systematic review. J Clin Oncol. 2008;26(24):4001-4011.

4. Bar-Ad V, Ohri N, Werner-Wasik M. Esophagitis, treatment-related toxicity in non-small cell lung cancer. Rev Recent Clin Trials 2012;7(1):31-35.

5. Dholaria B, Dang S, Arnaoutakis K, Hardee M. Chapter 7: Gastrointestinal side effects of palliative radiation therapy delivered via advanced technologies. In: Fairchild A, editor. Palliative Radiation Therapy: Utilization of Advanced Technologies. Vol. 2. New York, NY: Nova Science Publishers Inc; 2015:125-152.

6. Ahn S, Kahn D, Zhou S, Yu K, Hollis D, Shafman TD, Marks LB. Dosimetric and clinical predictors for radiation-induced esophageal injury. Int J Radiat Oncol Biol Phys. 2005;61(2):335-347.

7. Gomez D, Hunt M, Jackson A, et al. Low rate of thoracic toxicity in palliative paraspinal single-fraction stereotactic body radiation therapy. Radiother Oncol 2009;93(3):414-418.

8. Spiro S, Douse J, Read C, Janes S. Complications of lung cancer treatment. Semin Respir Crit Care Med 2008;29:302-318.

9. Chowhan NM. Injurious effects of radiation on the esophagus. Am J Gastroenterol. 1990;85(2):115-120.

10. Werner-Wasik M, Paulus R, Curran WJ Jr, Byhardt R. Acute esophagitis and late lung toxicity in concurrent chemoradiotherapy trials in patients with locally advanced non-small-cell lung cancer: analysis of the radiation therapy oncology group (RTOG) database. Clin Lung Cancer. 2011;12(4):245-251.

11. Bradley J, Movsas B. Radiation esophagitis: predictive factors and preventive strategies. Semin Radiat Oncol. 2004;14(4):280-286.

12. National Cancer Institute; National Institutes of Health; US Department of Health and Human Services. Common Terminology Criteria for Adverse Events (CTCAE); Version 4.0. Available from: http://evs.nci.nih.gov/ftp1/ CTCAE/CTCAE_4.03_2010-06-14_QuickReference_5x7.pdf. Accessed August 31, 2016

13. Hirota S, Tsujino K, Hishikawa Y, et al. Endoscopic findings of radiation esophagitis in concurrent chemoradiotherapy for intrathoracic malignancies. Radiother Oncol. 2001;58(3):273-278. 
14. Coia LR, Myerson RJ, Tepper JE. Late effects of radiation therapy on the gastrointestinal tract. Int J Radiat Oncol Biol Phys. 1995;31(5): 1213-1236.

15. O'Rourke IC, Tiver K, Bull C, Gebski V, Langlands AO. Cancer Swallowing performance after radiation therapy for carcinoma of the esophagus. Cancer. 1988;61(10):2022-2026.

16. Maguire PD, Sibley GS, Zhou SM, et al. Clinical and dosimetric predictors of radiation-induced esophageal toxicity. Int J Radiat Oncol Biol Phys. 1999;45(1):97-103.

17. Howell D. The role of radiation therapy in the palliation of gastrointestinal malignancies. Gastroenterol Clin N Am 2006;35(1):125-130.

18. Langer C, Hsu C, Curran W, et al. Do elderly patients with locally advanced non-small cell lung cancer benefit from combined modality treatment? A secondary analysis of RTOG 94-10. Int J Radiat Oncol Biol Phys. 2001;51(1 Suppl):20-21.

19. Challand T, Thureau S, Dubray B, Giraud P. Esophageal toxicity of radiation therapy: clinical risk factors and management. Cancer Radiother. 2012;16(5-6):364-371.

20. Patel AB, Edelman MJ, Kwork Y, Krasna MJ, Suntharalingam M. Predictors of acute esophagitis in patients with non-small cell lung carcinoma treated with concurrent chemotherapy and hyperfractionated radiotherapy followed by surgery. Int J Radiat Oncol Biol Phys. 2004;60(4):1106-1112.

21. De Ruysscher D, Dehing C, Bremer RH, et al. Maximal neutropenia during chemotherapy and radiotherapy is significantly associated with the development of acute radiation-induced dysphagia in lung cancer patients. Ann Oncol. 2007;18(5):909-916.

22. Lutz S, Chow E, Hartsell W, et al. A review of hypofractionated palliative radiotherapy. Cancer 2007;109:1462-1470.

23. O'Rourke N, Roque IFM, Farre Bernado N, Macbeth F. Concurrent chemoradiotherapy in non-small cell lung cancer. Cochrane Database Syst Rev. 2010;(6):CD002140.

24. Byhardt RW, Scott C, Sause WT, et al. Response, toxicity, failure patterns, and survival in five Radiation Therapy Oncology Group trials of sequential and/or concurrent chemotherapy and radiotherapy for locally advanced non-small-cell carcinoma of the lung. Int J Radiat Oncol Biol Phys. 1998;42(3):469-478.

25. Harvey J, Bessell J, Beller E, et al. Chemoradiation therapy is effective for the palliative treatment of malignant dysphagia. Dis Esophagus 2004; 17(3):260-265.

26. Saunders M, Dische S, Barrett A, Harvey A, Gibson D, Parmar M. Continuous hyperfractionated accelerated radiotherapy (CHART) versus conventional radiotherapy in non-small-cell lung cancer: a randomised multicentre trial. CHART Steering Committee. Lancet. 1997;350(9072):161-165.

27. Palma DA, Senan S, Oberije C, et al. Predicting esophagitis after chemoradiation therapy for non-small cell lung cancer: an individual patient data meta-analysis. Int J Radiat Oncol Biol Phys. 2013;87(4):690-696.

28. Bradley JD, Paulus R, Komaki R, et al. Standard-dose versus high-dose conformal radiotherapy with concurrent and consolidation carboplatin plus paclitaxel with or without cetuximab for patients with stage IIIA or IIIB non-small-cell lung cancer (RTOG 0617): a randomised, twoby-two factorial phase 3 study. Lancet Oncol. 2015;16(2):187-199.

29. National Lung Cancer Audit [Project Team]; Royal College of Physicians. Lung Cancer Consultant Outcome Publication 2016 (for the audit period 2013). Available from: www.rcplondon.ac.uk/projects/outputs/ lung-cancer-consultant-outcome-publication-2016-audit-period-2013. Accessed August 28, 2016.

30. Metcalfe S, Milano M, Bylund K, Smudzin T, Rubin P, Chen Y. Splitcourse palliative radiotherapy for advanced non-small cell lung cancer. J Thor Oncol. 2010;5(2):185-190.

31. Marks LB. Use of normal tissue complication probability models in the clinic. Int J Radiat Oncol Biol Phys. 2010;76(3 Suppl):S10-S19.

32. Bradley J, Deasy JO, Bentzen S, El-Naqa I. Dosimetric correlates for acute esophagitis in patients treated with radiotherapy for lung carcinoma. Int J Radiat Oncol Biol Phys. 2004;58(4):1106-1113.
33. Singh AK, Lockett MA, Bradley JD. Predictors of radiation-induced esophageal toxicity in patients with non-small-cell lung cancer treated with three-dimensional conformal radiotherapy. Int J Radiat Oncol Biol Phys. 2003;55(2):337-341.

34. Werner-Wasik M, Yorke E, Deasy J, Nam J, Marks LB. Radiation dose-volume effects in the esophagus. Int $J$ Radiat Oncol Biol Phys. 2010;76(3 Suppl):S86-S93.

35. Emami B, Lyman J, Brown A, et al. Tolerance of normal tissue to therapeutic irradiation. Int J Radiat Oncol Biol Phys. 1991;21(1): 109-122.

36. Brizel DM, Wasserman TH, Henke M, et al. Phase III randomized trial of amifostine as a radioprotector in head and neck cancer. J Clin Oncol. 2000;18(19):3339-3345.

37. Komaki R, Lee JS, Milas L, et al. Effects of amifostine on acute toxicity from concurrent chemotherapy and radiotherapy for inoperable nonsmall cell lung cancer: report of a randomized comparative trial. Int J Radiat Oncol Biol Phys. 2004;58(5):1369-1377.

38. Antonadou D. Radiotherapy or chemotherapy followed by radiotherapy with or without amifostine in locally advanced lung cancer. Semin Radiat Oncol. 2002;12(Suppl 1):50-58.

39. Werner-Wasik M, Axelrod SA, Friedland DP, et al. Phase II trial of twice weekly amifostine in patients with non-small cell lung cancer treated with chemotherapy. Semin Radiat Oncol. 2002;12(Suppl 1):34-39.

40. Movsas B, Scott C, Langer C, et al. Randomized trial of amifostine in locally advanced non-small-cell lung cancer patients receiving chemotherapy and hyperfractionated radiation: radiation therapy oncology group trial 98-01. J Clin Oncol. 2005;23(10):2145-2154.

41. Sarna L, Swann S, Langer C, et al. Clinically meaningful differences in patient-reported outcomes with amifostine in combination with chemoradiation for locally advanced non-small-cell lung cancer: an analysis of RTOG 9801. Int J Radiat Oncol Biol Phys. 2008;72(5):1378-1384.

42. Hensley ML, Hagerty KL, Kewalramani T, et al. American Society of Clinical Oncology 2008 clinical practice guideline update: use of chemotherapy and radiation therapy protectants. J Clin Oncol. 2009;27(1):127-145.

43. Vidal-Casariego A, Calleja-FernándezA, Ballesteros-Pomar MD, CanoRodríguez I. Efficacy of glutamine in the prevention of oral mucositis and acute radiation-induced esophagitis: a retrospective study. Nutr Cancer. 2013;65(3):424-429.

44. Algara M, Rodríguez N, Viñals P, et al. Prevention of radiochemotherapy-induced esophagitis with glutamine: results of a pilot study. Int $J$ Radiat Oncol Biol Phys. 2007;69(2):342-349.

45. M.D. Anderson Cancer Center. Randomized Trial of Glutamine in Patients with Mucositis or Esophagitis. In: ClinicalTrials.gov [Internet]. Bethesda (MD): National Library of Medicine (US); 2000 [cited 2016 Feb 28]. Available from: https://clinicaltrials.gov/ct2/show/ NCT01952847 NML Identifier: NCT01952847.

46. Milas L, Nishiguchi I, Hunter N, Murray D, Fleck R, Ito H, Travis E. Radiation protection against early and late effects of ionizing irradiation by the prostaglandin inhibitor indomethacin. Adv Space Res. 1992;12(2-3):265-271.

47. Nicolopoulos N, Mantidis A, Stathopoulos E, et al. Prophylactic administration of indomethacin for irradiation esophagitis. Radiother Oncol. 1985;3(1):23-25

48. Koukourakis MI, Flordellis CS, Giatromanolaki A, et al. Oral administration of recombinant human granulocyte macrophage colony-stimulating factor in the management of radiotherapy-induced esophagitis. Clin Cancer Res. 1999;5(12):3970-3976.

49. Rashad UM, Al-Gezawy SM, El-Gezawy E, Azzaz AN. Honey as topical prophylaxis against radiochemotherapy-induced mucositis in head and neck cancer. J Laryngol Otol. 2009;123(2):223-228.

50. Motallebnejad M, Akram S, Moghadamnia A, Moulana Z, Omidi S. The effect of topical application of pure honey on radiation-induced mucositis: a randomized clinical trial. J Contemp Dent Pract. 2008;9(3): $40-47$. 
51. Berk LD, Deshmukh S, Fogh SE, et al. Randomized phase 2 trial of best supportive care: manuka honey liquid and manuka honey lozenges for prevention of radiation esophagitis during chemotherapy and radiation therapy for lung cancer. Int J Radiat Oncol Biol Phys. 2014;90(1 Suppl):S5.

52. Perez RA, Early DS. Endoscopy in patients receiving radiation therapy to the thorax. Dig Dis Sci. 2002;47(1):79-83.

53. Murro D, Jakate S. Radiation esophagitis. Arch Pathol Lab Med. 2015;139(6):827-830.

54. Cox JD, Pajak TF, Asbell S, et al. Interruptions of high-dose radiation therapy decrease long-term survival of favorable patients with unresectable non-small cell carcinoma of the lung: analysis of 1244 cases from 3 Radiation Therapy Oncology Group (RTOG) trials. Int J Radiat Oncol Biol Phys. 1993;27(3):493-498.

55. Berkey FJ. Managing the adverse effects of radiation therapy. Am Fam Physician. 2010;82(4):381-388.

56. Sasso FS, Sasso G, Marsiglia HR. Pharmacological and dietary prophylaxis and treatment of acute actinic esophagitis during mediastinal radiotherapy. Dig Dis Sci. 2001;46(4):746-749.

57. Seres DS, Valcarcel M, Guillaume A. Advantages of enteral nutrition over parenteral nutrition. Therap Adv Gastroenterol. 2013;6(2):157-167.

58. Huang JO, Hunt RH. Meta-analysis of comparative trials for healing erosive esophagitis with proton pump inhibitors and H2-receptor antagonists. Gastroenterology. 1998;114(1 Suppl):A154-A155.
59. Sur RK, Kochhar R, Singh DP. Oral sucralfate in acute radiation oesophagitis. Acta Oncol. 1994;33(1):61-63.

60. Taal BG, Vales Olmos RA, Boot H, Hoefnagel CA. Assessment of sucralfate coating by sequential scintigraphic imaging in radiationinduced esophageal lesions. Gastrointest Endosc. 1995;41(2): 109-114.

61. McGinnis WL, Loprinzi CL, Buskirk SJ, et al. Placebo-controlled trial of sucralfate for inhibiting radiation-induced esophagitis. J Clin Oncol. 1997;15(3):1239-1243.

62. Egan JV, Baron TH, Adler DG, et al. Esophageal dilation. Gastrointest Endosc. 2006;63(6):755-760.

63. Aupérin A, Le Péchoux C, Rolland E, et al. Meta-analysis of concomitant versus sequential radiochemotherapy in locally advanced non-small-cell lung cancer. J Clin Oncol. 28(13):2181-2190.

64. Modh A, Rimner, A, Williams E, et al. Local control and toxicity in a large cohort of central lung tumors treated with stereotactic body radiotherapy. Int J Radiat Oncol Biol Phys. 2014;90(5):1168-1176.

65. Timmerman R, Paulus R, Galvin J, et al. Stereotactic body radiation therapy for inoperable early stage lung cancer. JAMA. 2010;303(11): 1070-1076.

66. RTOG Foundation Inc. RTOG/EORTC Late Radiation Morbidity Scoring Schema. Available from: https://www.rtog.org/ResearchAssociates/ AdverseEventReporting/RTOGEORTCLateRadiationMorbidityScoringSchema.aspx. Accessed August 31, 2016.
Lung Cancer: Targets and Therapy

\section{Publish your work in this journal}

Lung Cancer: Targets and Therapy is an international, peer-reviewed, open access journal focusing on lung cancer research, identification of therapeutic targets and the optimal use of preventative and integrated treatment interventions to achieve improved outcomes, enhanced survival and quality of life for the cancer patient. Specific topics covered in the journal include: Epidemiology, detection and screening Cellular research and biomarkers; Identification of biotargets and agents with novel

Submit your manuscript here: https://www.dovepress.com/lung-cancer-targets--therapy-journa
Dovepress

mechanisms of action; Optimal clinical use of existing anticancer agents, including combination therapies; Radiation and surgery; Palliative care; Patient adherence, quality of life, satisfaction; Health economic evaluations. The manuscript management system is completely online and includes a very quick and fair peer-review system. Visit http://www.dovepress.com/testimonials.php to read real quotes from published authors. 